\title{
Qualifications of Physics Teachers in ICT to Integrate the Use of ICT in Moroccan Physics Schools: Obstacles and Solutions
}

\author{
Khalid Mahdi \\ Université Abdelmalek Essaâdi, ENS, LIRIP, Martil, Morocco \\ mahdikh@hotmail.com \\ Mohamed Laafou \\ Université Abdelmalek Essaâdi, ENS, LIRIP, Martil, Morocco \\ medlaafou@gmail.com \\ Rachid Janati-Idrissi \\ Université Abdelmalek Essaâdi, ENS, LIRIP, Martil, Morocco \\ rachjanati@yahoo.fr
}

\section{Doi:10.5901/jesr.2015.v5n1p177}

\begin{abstract}
In this paper, we focus on the qualification of physics sciences teachers in terms of the integration of the use of the in Information and Communication Technology (ICT) in Moroccan physics school, Continuous training courses for the teachers ICT are vital to improve the teaching quality, pedagogical skills also to update a teaching disciplinary. However, Moroccan teachers are not often profit from continuous training courses in ICT in general and especially ineducational simulation softwares. We propose in this paper distance learning ineducational simulation softwares. The objective of this distance learning is to ease the use of ICT in general and the educational simulation softwares for all the Moroccan teachers of physics sciences. This distance training courses will combines by the elements of flexibility and efficiency, flexible in terms of time and space because the physics teachers can have their training at any time they like and where ever they are whithout needed to displace, also flexible in term of choosing the desired and needed courses. Also this training is efficient because it is professional one and offers to the physics teachers the needed educational simulation softwares.
\end{abstract}

Keywords: teachers qualifications, distance training, ICT, physics teachers, continuous training, educational simulation softwares, Morocco

\section{Introduction}

Education and training play an essential role in the preservation, development and continuation of human civilization. In the era of scientific and technological revolution nowadays, education and training are becoming the main motive force for the developmental acceleration and considered as a determining factor for the success or failure of a nation in international competitions and for the success of each individual in his life. Thus, the Government and people of every nation highly appreciate the role of education and training. Therefore, they are officially in Morocco classified in the second national priority after the territorial integrit (NAJAH 2008). Thus, it was required to assume a profound reflection to restructuring the education and qualifications of teachers, which should be the subject of special attention.

Thence the MEN (Moroccan Minister of Education) launched in 2005 the GENIE program (Programme Génie 2005 ) (Generalization of Information Technologies and Communication in Education in Morocco), which aims to improve the quality of education by the integration and generalization of information communication and technology (ICT) in education, based on three important and complementary pillars: The infrastructures pillar, which concerne the equipment of schools with multimedia classrooms connected to the Internet. The content developments pillar, which focuses on the development of digital educational content to support the curriculum. The ICT trainings pillar, which aims to give teachers the necessary foundation for the use of computer tools.

Little research treats the obstacles of the integration of ICT in education in general and in physics sciences in particular, the aims of this integration is to improve quality of teaching and learning (MEN 1999), which is confirmed by 
several researches.

In 2011 Ouidadi conferm the almost total absence of training (initial and continuing) in ICT tools and the how to use it in education, while the teachers hope to receive a training in the field of ICT, but the initiatives for the acquisition of technological pedagogical skills required for teaching are inadequate (Ouidadi, O. et al., 2011).

In this paper, we treat the obstacle of qualification and ICT training courses for the physics science teachers, while the MEN has launched an initial computer training aims to train 230,000 people (teachers, inspectors, technicians, principals ...) durating the period of 2009 - 2013 (MEN 2008), Also we treat the solution that we intreduce to help physics science teachers to improve thier qualifications in ICT by distance learning about how to use educational simulation software in classrooms thus will ease and encourage teachers to use the ICT in thier classrooms, also according to Westwood (2003), the application of ICT to teaching and learning can provide many benefits such as, facilitating communication, increase access to information, improve motivation, increase problem solving capabilities and enable deeper understanding of complex ideas. ICT can provide pupils with special educational needs improved access to learning and areas of the curriculum which may have been previously inaccessible.

\section{Background and Problematic}

Several changes underway in the Moroccan educational system aim to improve the quality of education and training to respond more effectively to the demands of modernization and the challenges of globalization. Formally, the area of teacher training is one of the keys to any kind of reform such as education system. Also, «Teachers have the right to benefit from a powerful initial training and continuing education opportunities, allowing them to continually improve the level of their educational practice and to best perform their missions» (COSEF 1999).

Teachers training, both initial and continuous, can renew their teaching methods to encourage innovation in education, mobilize elements of knowledge and expertise in their teaching practices. Thus, teachers are encouraged to develop their professional skills and even acquire new skills in order to make their teaching more effective.

Little research has addressed the practices and obstacles to the integration of ICT in the physics sciences in Morocco. (Ahaji, K., et al., 2008) affirm that the integration of ICT has a positive effect in teaching and learning in geometrical optics, K. Mahdi and al. Affirme that the Distance training for teachers can, help teachers improve their methods and teaching strategy updating their knowledge in physics science (Mahdi, K. et al., 2014), Also, most research on the use of computer simulations has been approached without consideration of the possible impact of teacher support, the lesson scenario and the role of computer simulation in the program (Rutten, N. et al., 2012). These factors may increase the performance of learners in the acquisition of concepts and physics phenomena.

On the other hand the results of Alj and Benjelloun show that $94.4 \%$ of teachers surveyed expressed great interest in the use of ICT in their teaching practices. However, only $8 \%$ of them integrate ICT in the classroom on a regular basis (Alj, O. et al., 2013). While Biaz after a survey shows that the percentage of teachers who have received training in ICT "in the context of continuing training courses" does not exceed 20\% (Biaz, A., et al., 2009). This raises the question of generalization of training to all teachers and leads us to think seriously to have an model to generalized the continuous training courses to all the teachers. Indeed, the part relating to evaluate and assisting beneficiaries after completion of training should be considered. From that we propose an efficient flexible continuous distance learning for teachers of physics science in ICT Flexibility of 'anytime, anywhere' access

(Jacobsen and Kremer, 2000), this proposition gives the teachers the opportunity to have every needed continuous training courses in ICT to initialize and update their knowledge without the obstacles of time and displacement. Thus, this training aims to encourage the integration of ICT in the physics classrooms.

\section{Methodology}

\subsection{Sample}

In this section we present the results of a recent study (Janvier 2014) with 80 physics teachers belonging to 17 high schools of the Academy of Tetouan Tangier. The response rate to the questionnaire was $96,38 \%$.

The aim was to highlight on the one hand, the idea that physics teachers has concerning to the previous ICT training courses. On the other hand, to detect their vital needs in ICT. 


\subsection{Instrument}

To do this, a survey questionnaire was sent to physics teachers during the month of September 2013, the questionnaire was in Arabic and it was given directly to respondents.A small accompanying word instructed to inform respondents about the goals and the progress and objectives of the survey was attached to the questionnaire. The questionnaire was constructed with a closed-ended questions. In total, there were 13 questions.

\subsection{Advantages of Closed-Ended Questions}

- Closed-ended questions are more easily analyzed. Every answer can be given a number or value so that a statistical interpretation can be assessed. Closed-ended questions are also better suited for computer analysis. If open-ended questions are analyzed quantitatively, the qualitative information is reduced to coding and answers tend to lose some of their initial meaning. Because of the simplicity of closed-ended questions, this kind of loss is not a problem.

- Closed-ended questions can be more specific, thus more likely to communicate similar meanings. Because open-ended questions allow respondents to use their own words, it is difficult to compare the meanings of the responses.

- In large-scale surveys, closed-ended questions take less time from the interviewer, the participant and the researcher, and so is a less expensive survey method. The response rate is higher with surveys that use closed-ended question than with those that use open-ended questions (Barribeau, P. et al., 2005).

We present below the main results of our investigation.

\section{Results}

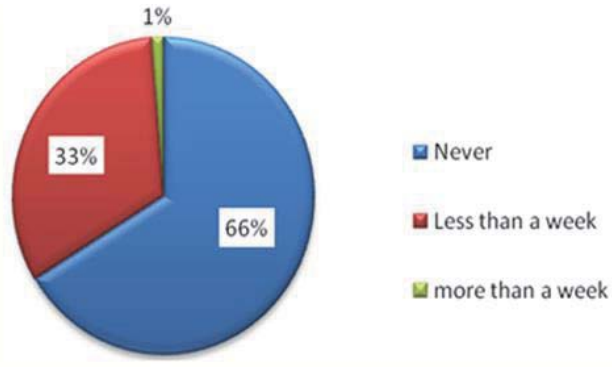

Fig.1 Days of ICT training courses that physic teachers received

The results of the questionnaire showed in the graph above seems clear that more than two thirds of physics science teachers have never benefited from any ICT training courses, while the remaining one-third of the teachers had benefited from a Short term training which does not exceed the duration of one week

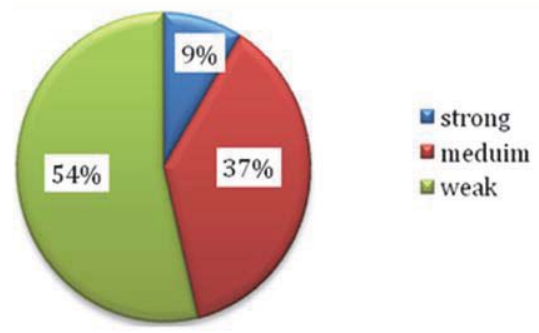

Fig.2 Relation between the previous ICT training and teachers needs

Most of physics teachers who had benifit from the ICT training courses believe that the training followed are not suitable with their specific needs, but only $9 \%$ from those teachers are satisfied. 


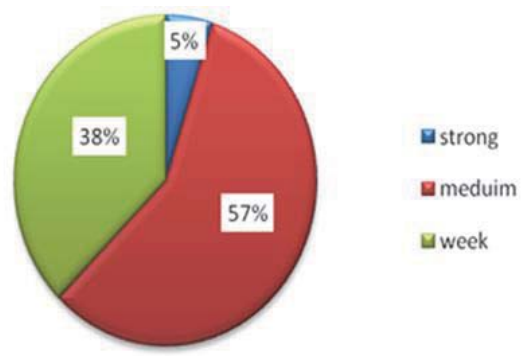

Fig.3 Consistency of the group of physics teachers in the previous ICT training courses

The graph above shows that only $5 \%$ of physics scince teachers see that the selected training group is consistent in terms of their level of ICT as well as their specialty

In the questionnaire teachers mark thier levels in some ICT software, And the results were as shown in graph below:

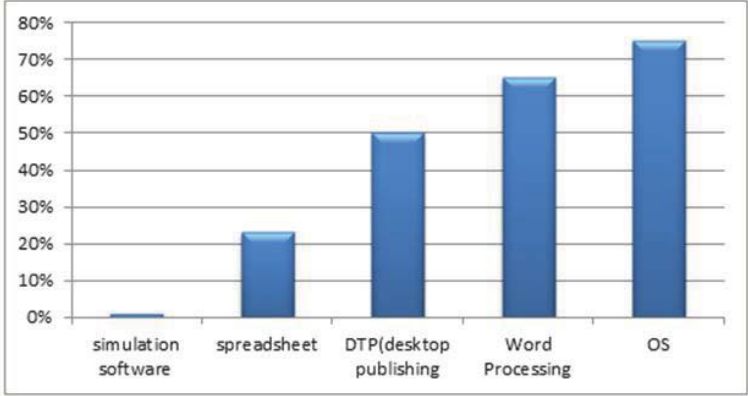

Fig.4 The competence of teachers in ICT tools

The average of competence of teachers in simulation softwares is less than $1 \%$, which mean that the physics scince teachers should have a heavy countinuous training courses in the field of educational simulation softwares.

The questionnaire also allow the physics teachers to express their needs to the computer softwares and others ICT tools that can be used in their professional practices.

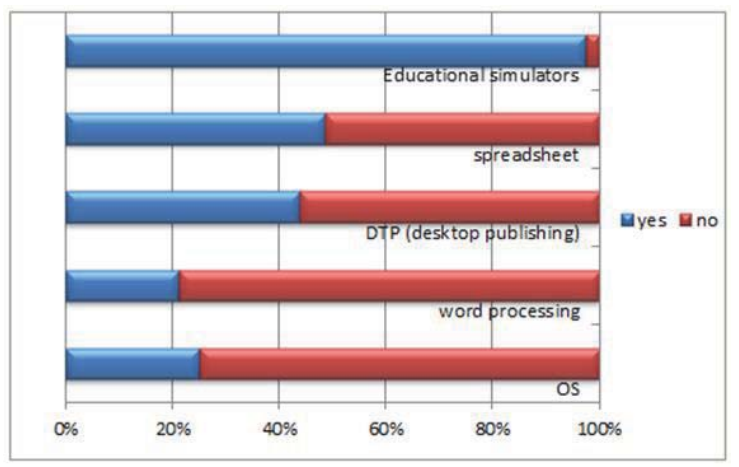

Fig.5 The needs of teachers in ICT tools

With regard to the needs of teachers in training, over than 97\% expressed their desire to have special training in the field of education simulators softwares, on the other hand the rate of spreadsheet and DTP (desktop publishing) is almost $50 \%$, regarding to the word processing and operation system the ratio was in the range of $22 \%$.

In connection with the motivation of the physics scinece teachers to follow online ICT training courses, more than two-thirds of them expressed that they have a big motivation 


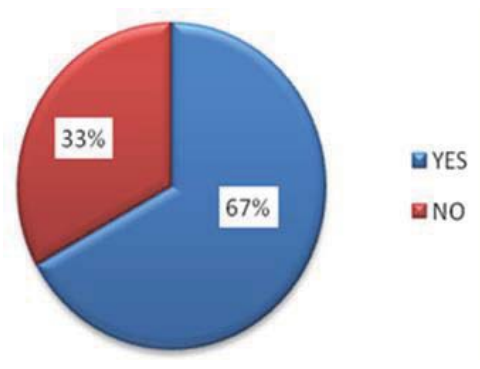

Fig.6 Motivation of physics teachers to follow online training in ICT

\section{Discussion}

In this section, we discuss the results of the survey to know the major obstacles of the integration of the ICT in the physics classrooms which influence on the physics science qualification and we will try to bring a solution to them. Our results show clearly that:

1 The physics teachers are rarely receive continuous training in ICT, and these conventional training courses are limited in time. That is why we should look to generalize the training for all teachers and to have a long term training courses without causing dropout of school while teachers are undertaking training.

2 The previous trainings do not take into account the specific needs of the physics science teachers in terms of required computer software's, especially the physics simulation software's.

3 The previous trainings do not take into consideration the material taught of teachers nor their ICT level. Teachers group should take on consideration the basics of their material taught.

4 Focus must be put on the physics simulation software's in the trainings to respond to the needs of all the teachers.

5 On the other hand, we asked teachers about their motivations for a distance continuous training in ICT. The results of our research have encouraged us to offer an online training for those teachers in order to remedy the problems encountered in face to face training. In fact, online courses offer a Greater flexibility for teachers in choosing the timing and content of their learning. In addition, online training will last much longer than the duration of face-to-face training.

\section{Suggested Solutions}

Our research is targeted to improve the talents, skills and qualification of physics scince teachers by proposing a distance countinuous training courses in ICT for all the physics science teachers. This training is based on an e-learning platform, which is rich, in ICT courses, so the teachers have the opportunity to choose any course at any time depending on their own desires and needs. Then they can start benefiting from those courses any time they like without any obstacles of time or displacement. Each course is divided into chapters, and each chapter consists of file text, videos lessons, animations and simulation software's. The teacher can also go to an online test to assess the skills acquired.

This platform is rich also with the physics science animation and simulation software's, so the teachers can download any needed software to use it in their teaching activities, and it also provides a space for physics teachers to share courses, simulation software's and discuss problems of physics science learning in order to seek solutions to these problems in collaboration with other teachers using some of synchronous communication (e.g. chat) and asynchronous (e.g. Forum).

\section{Conclusion}

The research that we conducted with teachers of the delegation of Tangier Tetouan of the country of Morocco, allowed us to put the finger on the obstacles of the ICT teachers qualification and to conclude that the best way to improve the skills of teachers in ICT is by proposing a continuous distance learning in ICT for the physics teachers this training should be:

1. Flexibile in term of time and space, so that the physics techears can start reading at any time and at any place without leaving his place of work and causing the wastage of school. 
2. The trainig should be opened for all the physics teachers all around the moroccan kingdom without exeption in orther that all of them can benifit from this ICT training courses.

3. This continuous trainig courses should be according to teachers desires and needs .

4. This training provide also lessons in physics educational simulation softwares in orther that the physics teachers learn about this kind of software and how they can use it in their classrooms to have an Higher quality lessons.

This kind of training can encourage and motivate physivs science teachers to integrate educational simulation softwares in thier courses and teir classromm activities easily and update thier knowledge in ICT thus will also motivated students to continue using learning outside school hours by using this educational simulation software.

\section{References}

Ahaji, K., El Hajjami, A., Ajana, L., El Mokri, A. et Chikhaoui, A. ( 2008a ). Analyse de l'effet d'intégration d'un logiciel d'optique géométrique sur l'apprentissage d'élèves de niveau baccalauréat sciences expérimentales. EpiNet, 101. Récupéré du site de l'association Enseignement Public et Informatique (EPI) : http://www.epi.asso.fr

Alj Omar and Nadia Benjelloun (2013) Intégration des TIC dans l'enseignement des sciences physiques au Maroc dans le cadre du programme GENIE: difficultés et obstacles Enseignement Public et Informatique ( EPI ) : http://www.epi.asso.fr

Biaz, A., Ahmed Bennamara, A. K., \& Talbi, M. (Décembre 2009 ). Intégration des technologies de l'information et de la communication dans le travail enseignant, état des lieux et perspectives. Enseignement Public et Informatique ( EPI ): http://www.epi.asso.fr.

Charte nationale d'éducation et de formation, Levier 16: Améliorer la gouvernance et l'évaluation continue du système éducation formation http://www.men.gov.ma/sites/fr/Lists/Pages/charte_espace5fr.aspx

Commission spéciale d'éducation et de formation ( COSEF ) ( 1999 ). Charte nationale d'éducation et de formation. Rabat : "Commission spéciale d'éducation et de formation, page : 6. disponible en ligne à : http://uh2c.ac.ma/uh2c/loi/charte_fr.pdf

Genie Program ( Generalization of Information Technologies and Communication in Education in Morocco ) http://www. men. gov. ma/ sites/fr/Lists/Pages/tice-contexte.aspx

Mahdi, K., Chekour, M., \& Laafou, M. ( 2014 ). Distance training for physics teachers in education sciences: flexible and efficient. International Journal of Scientific \& Engineering Research, Vol. 5, No. 1, pp. 77 - 80. Retrieved [ June 12, 2014 ] from http://www.ijser.org/onlineResearchPaperViewer.aspx?Distance-training-for-physics-teachers-in-education-sciences.pdf

Omar El Ouidadi, Khadija Essafi, Mohamed Aboutajdyne, Khalid Sendide et Eric Depiereux. "Analyse d'attitudes et de besoins d'enseignants marocains en TICE : Cas de l'académie (AREF) de FES-Boulemane, Maroc». RADISMA, Numéro 7 (2011), 3 décembre 2011, http://www.radisma.info/document.php?id=1145. ISSN 1990-3219

Paul Barribeau, Bonnie Butler, Jeff Corney, Megan Doney, Jennifer Gault, Jane Gordon, Randy Fetzer, Allyson Klein, Cathy Ackerson Rogers, Irene F. Stein, Carroll Steiner, Heather Urschel, Theresa Waggoner, and Mike Palmquist. (2005).

Survey Research.Writing@CSU. Colorado State University Department of English. Available at http://writing.colostate.edu/guides/ research/surveyl.

Westwood (2003) in Essays, UK. (November 2013) Ict Special Educational Needs. Retrieved from http://www.ukessays.com/ dissertations/information-technology/ict-special-educational-needs.php?cref=1

Rutten, N., van Joolingen, W. R. and van der Veen, J. T. ( 2012 ). The learning effects of computer simulations in science education. Computers \& Education, Vol. 58, No.1, 136-153.

Royaume Du Maroc, Ministère de l'Education Nationale, de l'Enseignement Supérieur, de la Formation des Cadres et de la Recherche Scientifique, "Rapport de synthèse du programme d'urgence 2009-2012, Available at http://www.men.gov.ma /sites/fr/PUspace/bib doc/SYNTHESE Fr.pdf

Jacobsen, D.M. and Kremer, R. , ( 2000 ). Online testing and grading using WebCT in computer science. Paper presented at WebNet 2000: World conference on the WWW and the Internet, San Antonio, Texas, 30 October - 4 November. Available at http://www.ucalgary.ca/ dmjacobs/seng/webnet2000_paper.html 